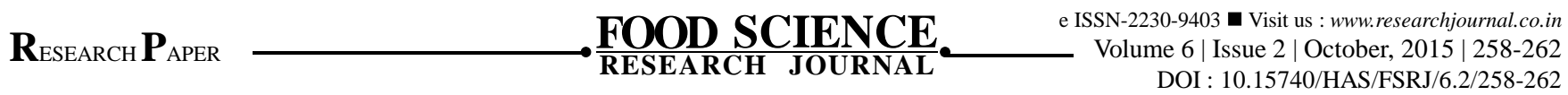

\title{
Microencapsulated iron for fortification in yoghurt
}

\author{
R. Subash and A. Elango
}

\begin{abstract}
Iron deficiency anaemia is a significant nutritional problem in south asian countries including India, Bangladesh and Pakistan than anywhere else in the world. Even though yogurt is an excellent source of calcium and protein, it contains very little iron. Using dairy foods as a vehicle for supplementing iron seems to be advantage as iron-fortified dairy foods have a relatively high iron bioavailability. Keeping this in view, a study was envisaged to formulate microencapsulated whey protein-chelated iron (Fe-wp) using ferrous sulphate that could be used in the development of iron fortified yoghurt to have highly bio available iron with no effect on nutritional value or sensory properties of the yoghurt. Influence of iron on survival of yoghurt culture, TBA values of yoghurt and sensory properties of yoghurt were tested by control, free iron and encapsulated iron fortification. Statistically no significant $(\mathrm{P}>0.05)$ difference was noticed in count of Lactobacillus delbrueckii ssp. bulgaricus and Streptococcus salivarius ssp. thermophilus between control and different iron fortified yoghurt treatments on 0, 7, 14 and 21 days. During storage period, the count of Lactobacillus delbrueckii ssp. bulgaricus and Streptococcus salivarius ssp. thermophilus significantly $(\mathrm{P}<0.05)$ decreased both in control and as well as in iron fortified yoghurt and thus the fortified iron did not affect the viability of yoghurt bacteria. The TBA values of unencapsulated iron fortified yoghurt was significantly $(\mathrm{P}<0.05)$ higher when compared to control and encapsulated iron fortified yoghurt. Significant $(\mathrm{P}<0.05)$ difference was observed in astringent and oxidized flavour at $0,7,14$ and $21^{\text {st }}$ day of storage between control and different treatments of yoghurt. In addition, significant $(\mathrm{P}<0.05)$ difference was observed in overall preference at $0,7,14$ and $21^{\text {st }}$ day of storage between control and different treatments of yoghurt and between different storage periods. It is demonstrated that microencapsulated whey protein chelated iron can be added up to a level of 80 $\mathrm{mg}$ per lit. of yoghurt without altering the accepted appearance and sensorial attributes.
\end{abstract}

Key Words : Microencapsulation, Ferrous sulphate, Dairy product, Yoghurt

How to cite this article : Subash, R. and Elango, A. (2015). Micro encapsulated iron for fortification in yoghurt. Food Sci. Res. J., 6(2): 258-262.

R. SUBASH, Department of Livestock Products Technology (Dairy Science), Veterinary College and Research Institute (T.N. Veterinary and Ani. Sci. Univ.), NAMAKKAL (T.N.) INDIA 